\title{
一般廃棄物及びバイオマスを用いた小型ガス化発電に関する研究*
}

\author{
孫永一*1, 矢尾板 大介*1 \\ 波 岡 知 昭*2, 吉川邦夫*2
}

\section{A Study on Small-scale Gasification and Power Generation from Municipal Solid Wastes and Biomass Fuels}

\author{
Young-il SON*3, Daisuke YAOITA, \\ Tomoaki NAMIOKA and Kunio YOSHIKAWA \\ ${ }^{* 3}$ Department of Environmental Science and Technology, Tokyo Institute of Technology, \\ 4259 Nagatsuta, Midori-ku, Yokohama-shi. Kanagawa, 226-8502 Japan
}

\begin{abstract}
We have been developing small-scale gasification and power generation systems utilizing solid wastes. Based on the R \& D achievements, a local town in Japan has built a $1 \mathrm{t} / \mathrm{h}$ scale slagging MSW (Municipal Solid Waste) gasifier combined with $900 \mathrm{~kW}$ dual-fueled diesel engines. This town will receives meat-and-bone meals to mix with MSW and feeds them into the plant as biomass fuels. It is expected that this plant will utilize $0.5 \mathrm{t} / \mathrm{h}$ MSW and $0.5 \mathrm{t} / \mathrm{h}$ meat- and-bone meals as fuels to generate $900 \mathrm{~kW}$ electric power. This paper describes the outline of this plant and discusses about effects of fuel composition and gasification air ratio on gasification performance as well as power generation results.
\end{abstract}

Key Words: Gasification, Power Generation, Municipal Solid Waste, Biomass Fuel

\section{1. 緒言}

廃棄物の焼却処理による排水・排ガスのダイオキシン 類による污染および化石燃料の枯渇等の問題を解決す る為の手段として国は,廃衰物処理の大規模化・広域化 を進め,併せて,廃裹物発電を推進している.しかし,大型 廃棄物処理施設に対する住民の反対や,離島などの広 域処理が困難な地方自治体があることを考えると,廃 萧物処理の広域化だけでは,上記の問題は解決出来な い.廃棄物発電の技術は,処理量 200 トン/日以上の一般 廃棄物処理施設において普及しつつあるが,産業廃棄 物処理施設およひ処理量 100 トン/日以下の小規模施 設では所内率が高く, 送電端効率が低く, 売電収入も少 なくて, 経済性もあまりよくないため 100t/d 規模で発 電を行っている施設は非常に少ないのが現状である. そこで, 中小規模でも高効率な発電が可能な, ガス化電

* 原稿受付 2006 年 1 月 19 日.

*1 学生員, 東京工業大学大学院総合理工学研究科 (业 226-8502 横浜市緑区長津田 4259 G 5-8)

*2 正員, 東京工業大学大学院総合理工学研究科.

E-mail : sonyi244@yk.depe.titech.ac.jp
技術が注目されている.一般廃棄物を対象とするガス 化発電については, わが国では, JFE グループのサーモ セレクト方式の 150 トン/日規模のプラントが唯一の 商用運転の事例であり ${ }^{(1)}$, 小規模な一般廃棄物処理施 設では,効率や経済性の問題等から,廃棄物発電は導入 されていない.主にバイオマスを対象とする小規模の ガス化発電システムについては, 木質系バイオマス燃 料における報告が多数されている(2).こうした背景か ら, 本研究室では, STAR - MEET (STeam/Air Reforming Type Multi-staged Enthalpy Extraction Technology）と呼 ばれるガス化発電システムについて, 研究を行ってき た.STAR -MEET システムの特徴としては, 1)高温の 水蒸気/空気混合気を熱分解ガスと直接接触させる改 質法により,酸素を使用せずに, タール分を $\mathrm{H}_{2}, \mathrm{CO}, \mathrm{CH}_{4}$ 等の軽質ガスに改質可能である 2)熱分解・改質は, 全 て還元雾囲気での反応である為, ダイオキシン類の発 生が少ない3)還元雾囲気での反忘である為, 廃棄物中 の $\mathrm{N}$ は $\mathrm{NH}_{3}, \mathrm{HCN}$ に変換され, 改質ガス中には $\mathrm{NO}_{\mathrm{x}}$ と して存在しない4)廃棄物中の重金属は, その大半が熱 
分解ガス化炉内の残渣である灰側に残り,ガス側には 殆ど移行しない, といら点が挙げられる. 現在までに, 本 STAR-MEET システムについては,超小型バイオマ スガス化発電装置の研究開発 ${ }^{(3)}$, 廃棄物ガス化発電用 混焼ディーゼル機関に関する研究(4), 小型廃棄物ガス化 発電システムのガス化発電特性 ${ }^{(5)}$,牛䔬を用いた熱分解 ガス化発電システムに関する研究(6)を初めとして,多く の基礎研究および実証研究を行ってきた ${ }^{(7)(8)}$ こうした 研究開発の成果に基ついて,人口約 7000 人の小規模な 自治体において,STAR-MEET システムを利用した一 般廃棄物発電プラントが設置され,稼動を始めている. 本論文では,本 STAR-MEET システムの概要を述べて, これまで得られたガス化・発電特性およびシステムの エネルギー収支の評価結果について報告する。

\section{2. ガス化発電システム及び設備の概要}

本ガス化発電施設は, 廃裹物処理量 1 トン/時であり, 町から排出される一般廃棄物(MSW) 0.5 トン/時と畜 産業者から処理を請け負った牛肉骨粉 0.5 トン/ 時を
Table 1 Composition of MSW, meat and bone meals and wood chips

\begin{tabular}{|c|c|c|c|}
\hline \multicolumn{5}{|c|}{ Proxim ate analysis } \\
\hline Item & MSW & Meat \& bone & Wood chips \\
\hline Moisture (wt\%) $^{* 1}$ & 43.5 & 3.9 & 12.1 \\
\hline${\text { Volatile (wt\%) }{ }^{* 2}}^{*}$ & 72.7 & 80.1 & 80.8 \\
\hline Fixed carbon (wt\%) $^{* 2}$ & 15.8 & 5.9 & 18.9 \\
\hline Ash (wt\%) ${ }^{* 2}$ & 11.5 & 14.0 & 0.3 \\
\hline \multicolumn{4}{|c|}{ Ultim ate analysis } \\
\hline $\mathrm{C}(\mathrm{wt} \%)^{* 3}$ & 55.4 & 56.5 & 49.7 \\
\hline $\mathrm{H}(\mathrm{wt} \%)^{* 3}$ & 8.6 & 7.7 & 6.6 \\
\hline $\mathrm{O}(\mathrm{wt} \%)^{* 3}$ & 34.8 & 22.4 & 43.4 \\
\hline $\mathrm{N} \mathrm{(wt \% )}{ }^{* 3}$ & 0.8 & 11.9 & 0.1 \\
\hline $\mathrm{Cl}(\mathrm{wt} \%)^{* 3}$ & 0.4 & 0.5 & 0.1 \\
\hline $\mathrm{S} \mathrm{(wt \% )}{ }^{* 3}$ & 0.0 & 1.0 & 0.1 \\
\hline $\mathrm{HHV}(\mathrm{MJ} / \mathrm{kg})^{* 2}$ & 15.5 & 21.8 & 19.3 \\
\hline
\end{tabular}

混合したものを処理対象としている.表 1 には処理対 象となる廃棄物の工業分析及び元素分析の結果を示 す。

なお, 後述するように, ガス化炉を安定化させるために, 一般廃棄物及び牛肉骨粉に加えて木屑も加えてあり,

$$
\text { MSW }
$$

Biomass fuel

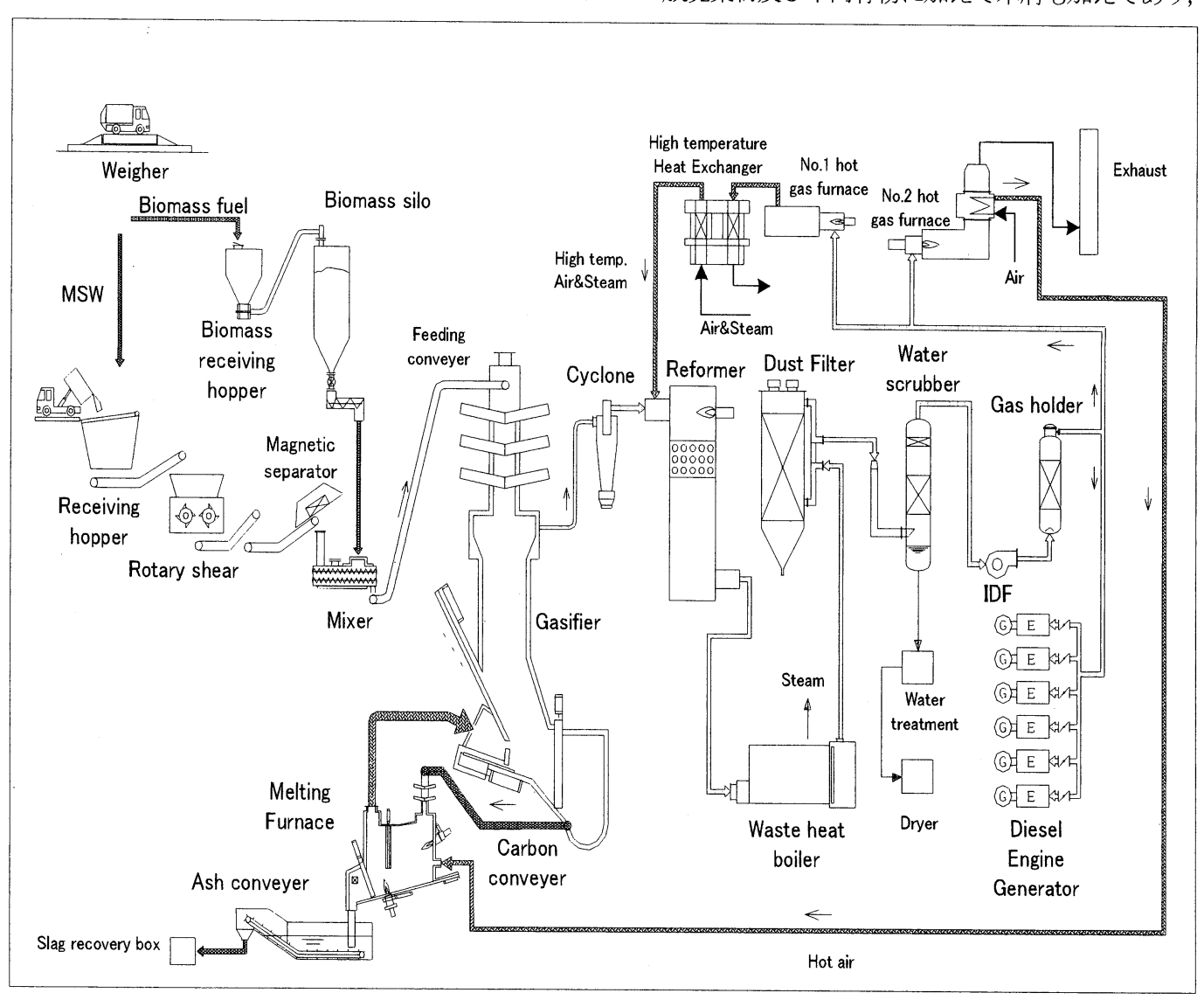

Fig.1 Flow diagram of the plant 
その分析結果も併せて示す。一般廃棄物は含水率 $40 \%$ 以上であり,近年の都市化によりプラスチックや紙の 割合が高くなって, 発熱量が増加する傾向があるが, 降 雨時は含水率が大幅に上昇したり, 組成も変動するな ど, 表 1 に示した值からの発熱量の変動はかなり大き い. 牛肉骨粉は乾燥されており発熱量は比較的高いが, 骨を主成分とする灰分の割合が大きく, 粉末状となっ ている.

本ガス化発電施設のフローを図 1 に示す.粗破砕され た一般廃棄物と牛肉骨粉は受入供給設備において混合 され, 固定床シャフト型のガス化炉において熱分解ガ ス化される. 熱分解後の炭素分を含んだ残渣は, 溶融炉 一移送後, 高温燃焼され, 排出される高温不活性燃焼ガ スは,ガス化炉における熱分解の熱源として利用され る. ガス化炉で発生した熱分解ガス中に含まれるター ル分は, 改質炉において高温水蒸気/空気混合気により 改質される.得られた改質ガスは, 廃熱ボイラにおいて 熱回収され, $200^{\circ} \mathrm{C}$ ゙降温され, 回収された熱は, 改質 炉において必要な水蒸気を生成するための熱源として 利用される. 改質ガス中のダストはバグフィルタで除 去された後に,ガス冷却精製塔において約 $40^{\circ} \mathrm{C}$ 以下ま で泠却・精製され, 混焼ディーゼルエンジン発電機での 発電用に使用される他,一部はNo.1及びNo.2熱風炉に おいて改質用空気/水蒸気及びガス化用空気の加熱に 用いられる. 改質用の高温水蒸気/空気混合気は, 回転 蓄熱式熱交換器によって, 上記の No.2 熱風炉で生成さ れる然焼ガスとの熱交換によって加熱される.混焼デ ィーゼルエンジン発電機は, 発熱量 $3.8 \mathrm{MJ} / \mathrm{m}^{3} \mathrm{~N}$ 程度以 上の燃料ガスで動作し, 熱量換算で $70 \%$ の燃料ガスと $30 \%$ の軽油をべースとした補助燃料を混焼させる事に より発電出力を得る. 本設備では, 発電出力 $150 \mathrm{~kW}$ の 混焼ディーゼルエンジン発電機が 6 台設置されてい る.

表 2 には, 本ガス化発電施設の主要機器の仕様を示 す. 図 2 にガス化炉の構造を示す.ガス化炉は, 固定床 シャフト型で, 正圧にて運転され, 空気の漏れ込み, ガ ス漏れが起きないようにシールされている.ガス化炉 上部では, 熱分解ガスがサイクロンへと流れ出る煙道 があり,ガス化炬下部では，溶融炉からの高温燃焼ガス を吹き込む煙道, ガス化炉底部では, 溶融炉一炭化物を 送り出寸炭化物搬出コンベアが連結されている. 炉体 は炭化物排出口に向けて下降傾斜した構造をしている ため, 炉体内部の廃裹物, 炭化物は, 炭化物排出口に向 け, 流動性する.さらに, 炉体の傾斜に沿って廃棄物, 炭 化物を押し出す油圧のプッシャ機構が設けられており,
廃棄物, 炭化物の流動性が確保される仕組みになって いる.

Table 2 Specification of main components

\begin{tabular}{c|c|c}
\hline Device Name & Device Type & Specifications \\
\hline \hline Pyrolyzer & Fixed bed-type & $1.8 \mathrm{~m}^{2} \times 6.6 \mathrm{~m}$ \\
Melting Furnace & Water cooled wall & $1.2 \mathrm{~m}^{2} \times 2.5 \mathrm{~m}$ \\
Reformer & Ceramic pebble & $1.1 \mathrm{~m}^{2} \times 6.4 \mathrm{~m}$ \\
Boiler & Wasted heat boiler & Steam: $1300 \mathrm{Kg} / \mathrm{hr}$ \\
Dust filter & Glass fiber filter & Inlet temp.: $200^{\circ} \mathrm{C}$ \\
Gas cooling & Water scrubber & Outlet temp: $40^{\circ} \mathrm{C}$ \\
No.1 furnace & LPG/low-BTU gas & Temp. $: 1000^{\circ} \mathrm{C}$ \\
Heat Exchanger & Rotating ceramic & Temp.: $900^{\circ} \mathrm{C}$ \\
No.2 furnace & LPG/low-BTU gas & Temp.: $800^{\circ} \mathrm{C}$ \\
Air Pre-heater & Metallic type & Temp.: $500^{\circ} \mathrm{C}$ \\
Engine Power & Low-BTU gas and BDF & Output:900kWe \\
Generator & co-firing diesel engine & $(150 \mathrm{kWe} \times 6$ units $)$ \\
\hline
\end{tabular}

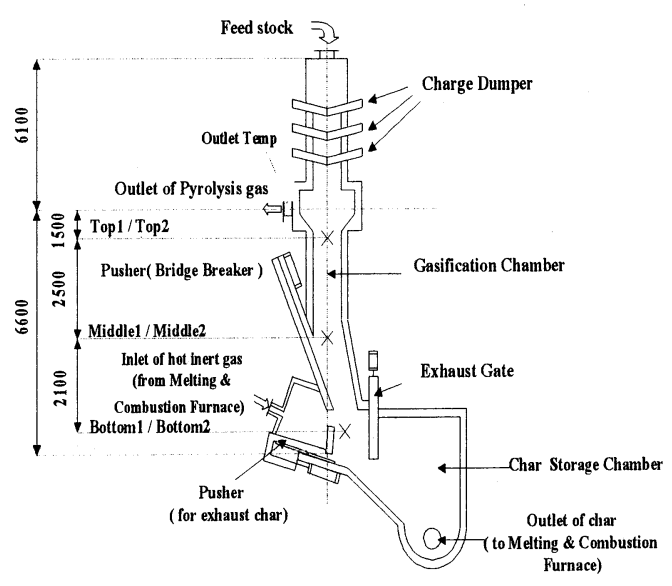

Fig.2 Structure of the gasifier

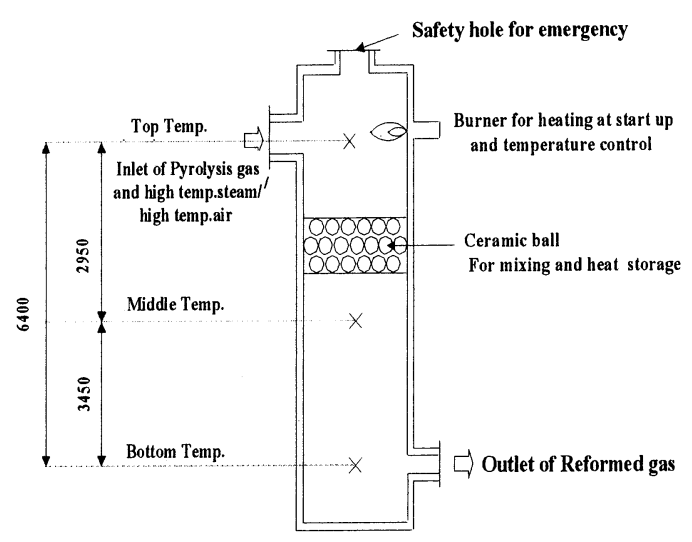

Fig.3 Structure of the reformer 
図3に改質炉の構造を示す. 改質炉は, 空気の洩れ込 み,ガス漏れが起きないようにシールされており, 改質 炉上部には, 改質に用いられる高温水蒸気/空気の供給 管, 改質炉昇温, 温度維持用のバーナが備え付けられて いる. また, 改質炉中央部には, 直径 50mm のセラミッ クボールが高さ $500 \mathrm{~mm}$ ほど充填されており, 熱エネル ギーを蓄えるバッファおよび熱分解ガスと高温水蒸気 /空気混合気との混合促進材として用いられ, 熱分解ガ スの供給量や発熱量に変動がある場合でも, ある程度 許容されるような構造になっている.

\section{3. 運転結果と考察}

本ガス化発電システムの基本的な特性を把握するた めに実施した, 一般廃棄物 $(45 \%)$ と牛肉骨粉 $(55 \%)$ を混合させた運転(RUN1), 一般廃棄物 $(60 \%)$, 肉骨粉 (30\%)及び木屑(10\%)を混合させた運転(RUN2)，一般 廃棄物( $30 \%)$, 肉骨粉 $(30 \%)$ 及び木屑 $(40 \%)$ を混合させた 運転(RUN3) について, 運転結果を示寸. 表 3 に各運転 の平均的な運転条件を示す. 予備的な運転の為, 廃棄物 の投入量は設計値の $50 \%$ 程度となっている. また, 本運 転では, 溶融炉においては, 炭化物の然焼は行わず,溶融 炉からガス化炉へ空気を吹き込む事によって,ガス化 炉底部で炭化物の然焼反応を起こさせ,生成される焼 却灰を溶融炉に送って搬出するという運転方式をとっ た.運転時にガスホルダ出口でサンプリングした燃料 ガス (改質ガス)については,不純物や水分を $10^{\circ} \mathrm{C}$ 以下 に冷却された水により除去した後に、マイクロガスク ロマトグラフで組成を測定し,その組成から計算によ り発熱量を求めた.

Table 3 Operational conditions of each RUN

\begin{tabular}{|c|c|c|c|}
\hline Run No. & RUN1 & RUN2 & RUN3 \\
\hline \multirow{3}{*}{ Feed material } & \multirow{3}{*}{$\begin{array}{c}\operatorname{MSW}(45 \%) \\
\text { Meat\&bone (55\%) }\end{array}$} & $\operatorname{MSW}(60 \%)$ & $\operatorname{MSW}(30 \%)$ \\
\hline & & Meat\&bone(30\%) & Meat\&bone(30\%) \\
\hline & & Wood Chip $(10 \%)$ & Wood Chip(40\%) \\
\hline Feed rate & $44(1 \sim 570 \mathrm{~kg} / \mathrm{h}$ & $36(1) 390 \mathrm{~kg} / \mathrm{h}$ & $35(1) 470 \mathrm{~kg} / \mathrm{h}$ \\
\hline Gasification air ratio & $0.39 \sim(1.54$ & $(0.25 \sim 1.40$ & $0.11 \sim 1.29$ \\
\hline Reforming air ratio & $0.08 \sim 1.17$ & $0.13 \sim(1.23$ & (1). (177 $\sim 1.14$ \\
\hline Reforming steam ratio & (1).38 -1.47 & $0.49 \sim(1.75$ & $0.43 \sim(1.71$ \\
\hline Reform air\&steam & $64\left(1 \sim 7010^{\circ} \mathrm{C}\right.$ & $58(1) 640^{\circ} \mathrm{C}$ & $64\left(1 \sim 690^{\circ} \mathrm{C}\right.$ \\
\hline Fuel gas flow & $1160 \sim 1460 \mathrm{~m}^{3} \mathrm{~N} / \mathrm{h}$ & $82\left(1 \sim 991 \mathrm{~m}^{3} \mathrm{~N} / \mathrm{h}\right.$ & $94\left(1 \sim 1220 \mathrm{~m}^{3} \mathrm{~N} / \mathrm{h}\right.$ \\
\hline
\end{tabular}

$3 \cdot 1$ 燃料種がガス化・改質特性に与える影響

図 4 に, 一般廃棄物と牛肉骨粉の混合物を燃料とする 運転(RUN1)における,改質後の燃料ガスの低位発熱量 (LHV) とガス化炉内温度の経時変化の一例を示す。
ガス化炉は底部から上部にかけて $900^{\circ} \mathrm{C}$ 程度の高温か ら,300 ${ }^{\circ} \mathrm{C}$ 程度の低温まで徐々に温度が低下する温度勾 配を持たせなければならないが,図 4 より,RUN1 では， 燃料ガスの低位発熱量は $0.8 \sim 3.3 \mathrm{MJ} / \mathrm{m}^{3} \mathrm{~N}$ の間で大きく 変動しており, $4 \mathrm{MJ} / \mathrm{m}^{3} \mathrm{~N}$ といら所定の発熱量が得られな かったことが分かる.そこで,ガス化炉内の温度に注目 すると,ガス化炉底部温度は $400 \sim 1000^{\circ} \mathrm{C}$ 間で大きく 変動し,ガス化炉中部温度は $250 \sim 500^{\circ} \mathrm{C}$,ガス化炉上部

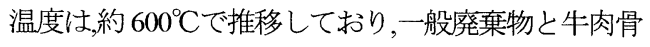
粉だけの運転では炉内温度が低く, 底部から上部にか けて温度が低下するという本来の温度勾配が形成され ていないことがわかる.それは,運転中に吹き抜けと呼 ばれる現象が起きているかららである考えられる.吹 き抜け現象が起こると, 廃棄物の充填層中を均一に高 温燃焼ガスが流れず,偏流を起こして炉内の廃棄物の 一部分のみが熱分解ガス化され，安定した反応が得ら れなくなる.加えて,ガス化炉上部温度が高い場合は,ガ ス化炉壁面からの放熱熱損失が大きくなる為,熱効率 が悪くなっていると考えられる.

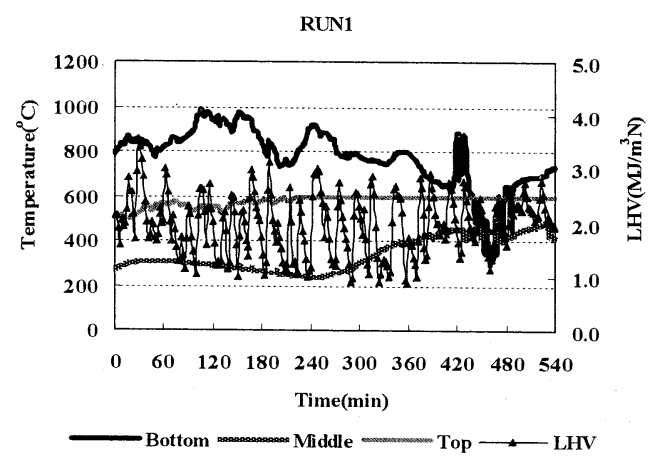

Fig.4 Historical trend of the fuel gas LHV and temperatures in the gasifier during 9 hours of RUN1

そこで,これまでの研究開発で得られた知見から,木 屑を混合させるとガス化炉において吹き抜けが生じに くくなり,燃料ガス低位発熱量が向上する事が分か力 ていることから,木屑を廃呆物に混合させた.眓 5 に木 屑を混合させた運転(RUN2 および3)の燃料ガスの低 位発熱量(LHV) とガス化炉内温度の経時変化の一例を 示寸.木屑混合率が $10 \%$ RUN2 では,ガス化炉底部温 度は, $600 \sim 750^{\circ} \mathrm{C}$,ガス化炉中部温度は, $400 \sim 600^{\circ} \mathrm{C}$,ガス 化炉上部温度は,約 $200^{\circ} \mathrm{C} て ゙$ 推移しており,燃料ガスの 低位発熱量には,RUN1 ほどではないが,やはり変動が 見られた.これは,ガス化炉底部温度が低いために熱分 解ガス化反応がまだ安定的に生じていないためと, 依 然として吹き抜け現象が解消していないからであると 
考えられる.それに対し,木屑混合率が $40 \%$ の RUN3 で

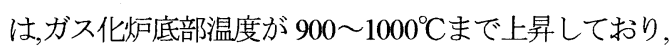
底部から上部にかけて予定通りの温度勾配が形成され ているため,吹き抜け現象が抑制され，低位発熱量 3.8 $\mathrm{MJ} / \mathrm{m}^{3} \mathrm{~N}$ 程度の然料ガスが安定的に生成されているこ とが分かる.このように,吹き抜け現象を抑制させた要 因の1つとして,燃料の高密度が影響していると考えら れる.これまでの研究開発の成果から,固定床ガス化炉 の場合,微粉状よりもペレット化された燃料のほうが 安定的な熱分解・ガス化反応が起こる事が判明してい る ${ }^{(9)}$. 投入した木屑は然料として適した粒径であり,偏 流が抑制されたと考えられる.それに対して,一般廃棄 物は破砕機にて破砕後も木屑と比較して粒径が大きく， 炉内において高密度が小さい為, 高温燃焼ガスの偏流 が起き易いと考えられる.また,牛肉骨粉は微粉状であ りここれも偏流を起こし易い燃料形状である.

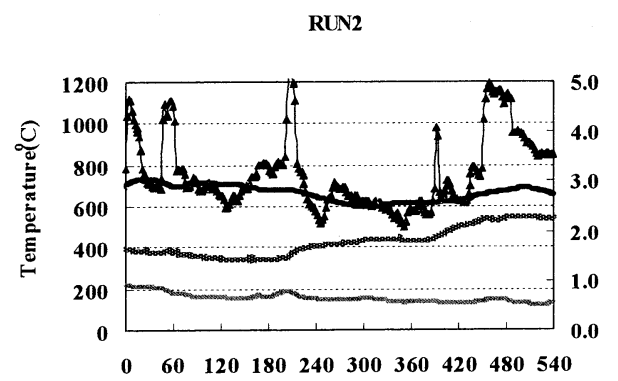

RUN3

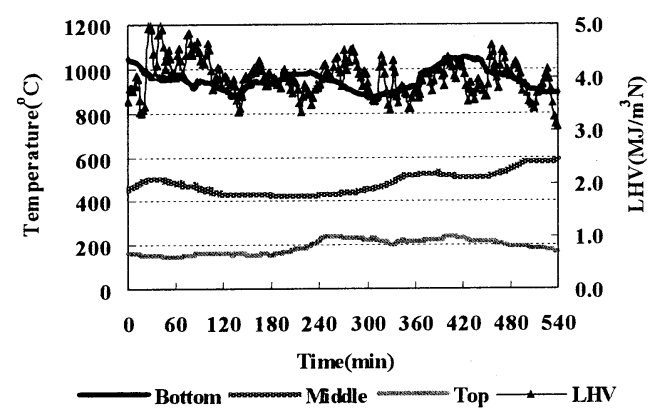

Fig.5 Historical trend of the fuel gas LHV and temperatures in the gasifier during 9 hours of RUN2 and 3

$3 \cdot 2$ ガス化空気比がガス化・改質特性に与える影響

3・1より吹き抜けの抑制策の1つとして, ガス化炉底 部の温度を $1000^{\circ} \mathrm{C}$ 程度まで上昇させることが重要であ ることを示した.そこで,ガス化空気比を変化させた時 のガス化炉底部温度の変化を図6に示す.ここで, ガス 化空気比は下式で定義される值である. ガス化空気比 の増加に伴い,いずれのRUNにおいてもガス化炉底部
の温度上昇が見られた.これは,ガス化炉への空気投入 量の増加により, チャーの燃焼反応が促進され, それに よってガス化炉底部温度が上昇したものと考えられる. しかし, RUN1では, 空気投入量を増加させても, RUN3 と比較し, $1000^{\circ} \mathrm{C}$ 程度まで,ガス化炉底部温度を上昇さ せることはできなかった. それは, 前述のように, 吹き 抜けが生じ, ガス化炉内に充填されている廃棄物の中 をガス化剤が均一に流れないからであると考えられ る.

$$
\text { ガス化空気比 }=\frac{\text { ガス化炉へ供給する空気中の酸素量 }(\text { mon) }}{\text { 蛿料の完全燃焼に要する酸素量 }(\text { mon })}
$$

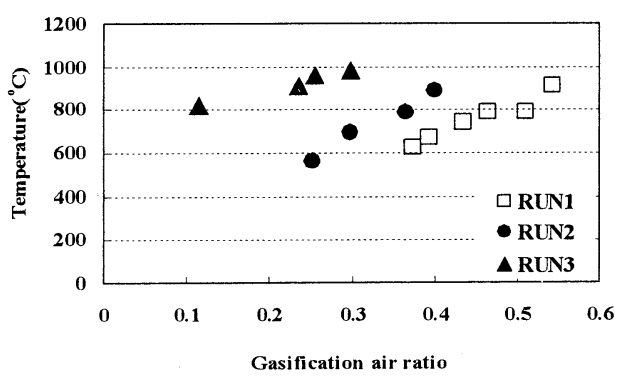

Fig.6 Relationship between gasification air ratio and temperature at the bottom part in the gasifier

図 7 にガス化空気比と燃料ガスの低位発熱量の関係 を示す. RUN3 では, ガス化空気比 0.1 0.3 で然料ガス 低位発熱量が約 $4.0 \mathrm{MJ} / \mathrm{m}^{3} \mathrm{~N}$ で安定していることが分か る. それに対し, RUN1,2 では,ガス化空気比の増加によ り, 燃料ガスの低位発熱量の増加が見られたが, RUN1 の場合, ガス化空気比 0.5 以上でも燃料ガスの低位発熱 量が約 $3.0 \mathrm{MJ} / \mathrm{m}^{3} \mathrm{~N}$ 止まりであり,RUN2 の場合, RUN3 と比較し,同程度の燃料ガス低位発熱量を得るために は, ガス化剂の不均一な流れに起因して,より多くのガ ス化空気を投入する必要があることが分かる.

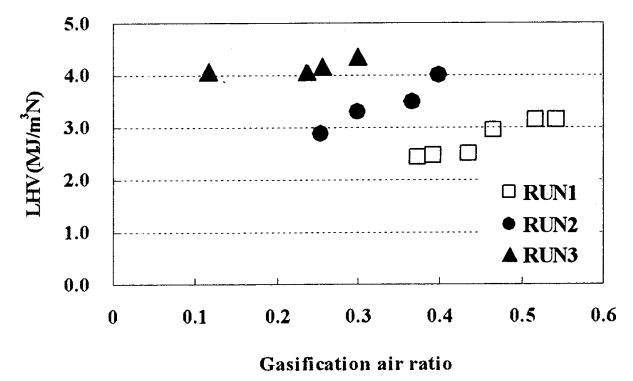

Fig.7 Relationship between LHV of the fuel gas and gasification air ratio 


\section{3 -3 改質空気比がガス化・改質特性に与える影響}

前述のように, ガス化炉に偏流が生ずると,ガス化炉 出口の熱分解ガスの性状も不安定となり, 相当変動す ることが予想される.そのため,改質用の空気量が一定 であると, 熱分解ガスの変動に応じて, 改質炉温度も変 動し, 熱分解ガス中のタールの改質が十分に行えなく なる恐れがある. そこで, 実際の運転では, 改質炉の温 度が $850^{\circ} \mathrm{C} \sim 950^{\circ} \mathrm{C}$ 範囲に収まるように, 改質空気の 流量を制御している.すなわち, 次式で定義される改質 空気比が, 制御パラメータとなる.ここで, 改質炉に供 給する水蒸気量は, $100 \mathrm{~kg} / \mathrm{h}$ のほぼ一定値に保持した.

$$
\text { 改質空気比 }=\frac{\text { 改質炬へ供給する空気中の酸素量 }(\text { mon) }}{\text { 然料の完全然烧に要する酸素量 }(\text { mol） }}
$$

Top
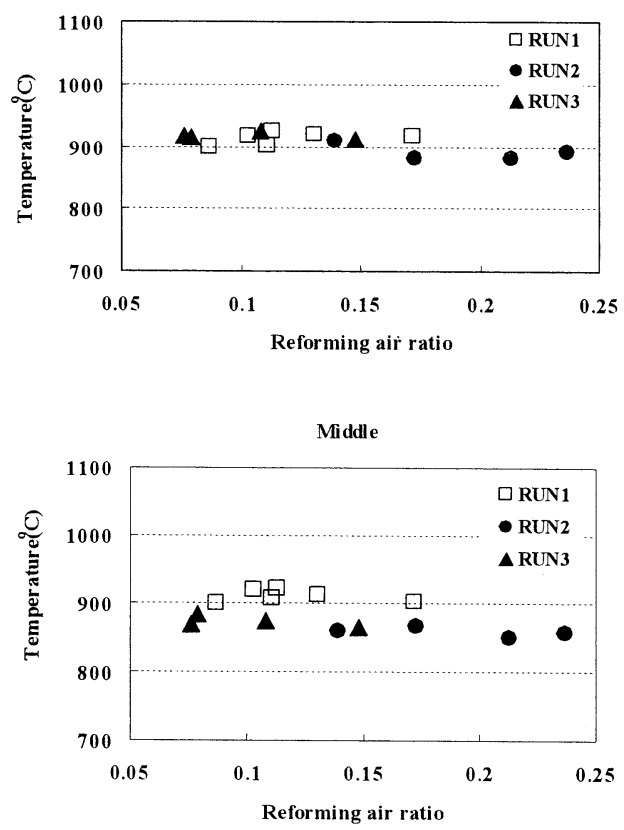

Bottom

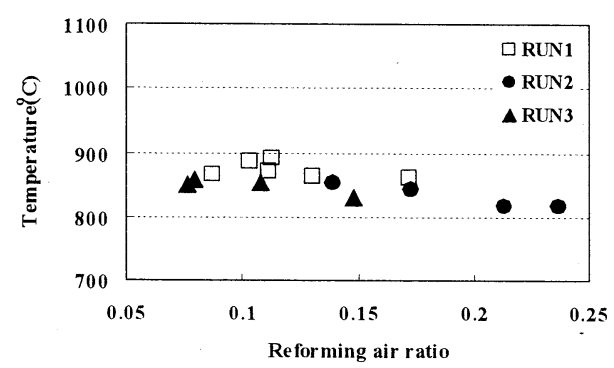

Fig. 8 Relationship between reforming air ratio and temperature in the reformer

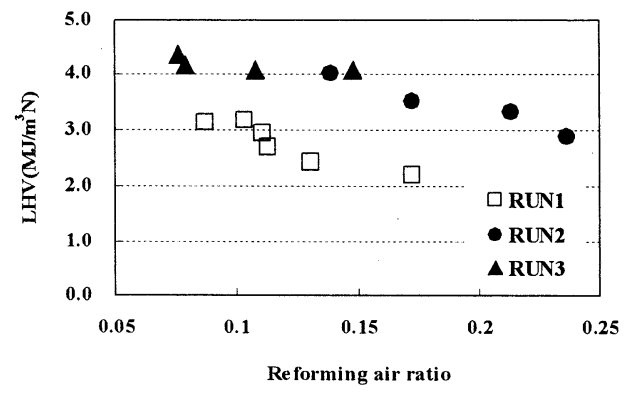

Fig.9 Relationship between LHV of the fuel gas and reforming air ratio

図 8 に, 改質炉温度を一定に保持するために, 各 RUN で, どの程度改質空気比を变化させたかを示す. この図から分かるように、いずれの RUNについても， 改質空気比の調整で, 改質炉内全体をほぼ一定の温度 に保つことが可能であることが分かる. RUN 3 と比較 し, RUN1,2 については改質炉温度を維持するために より広範に改質空気比を変化させる必要であり,それ だけ, 熱分解ガスの変動が大きいことが分かる. しかし， 図 9 に示すように,いずれのRUNについても改質ガス の低位発熱量は, 改質空気比の増加に伴い減少してい る. 改質炉内温度を維持するために, 改質空気比を増加 させると, タールおよび可燃性ガスの一部が燃焼され, その分, 改質ガスの低位発熱量が減少したものと考え られる.また, 改質空気比の増加に伴う窒素希釈量の増 大も, 燃料ガスの低位発熱量を減少させた要因の一つ であるものと考えられる. したがって, 改質空気比はあ まり大きくしないことが望ましく, RUN3 のように, 安 定にガス化させて, 小さめの改質空気比でも必要な改 質昵温度が維持できるようにすることが重要である.

なお, 改質ガス中の残留タール量については,ガスホ ルダ出口にて, 冷却した水を入れた捕集ビン中をガス を通して, タール分を水で捕獲し, 定量的な分析を試み たが, 定量化限界以下の濃度であった。

\section{$3 \cdot 4$ 発電特性}

表 5 に, 使用されている混焼ディーゼルエンジンの 仕様を示す.エンジンの手前にはフィルターが設けら れており，管内の不純物などを除去する.ガスの供給方 法は空気と混合され過給機を経てからシリンダーに供 給される.つまり, 軽油噴射量を一定にして, 固定出力 を得るための回転数制御は, ガス投入弁の開度の自動 調整による制御になっている. 発電運転時は, 一般廃棄 物, 肉骨粉, 木屑の混合物を使用したRUN3 で実施した. 
その時の平均的な改質ガス組成を表 6 に示す.また, 表 7 に, 混焼率 (発電機への総入熱量に対するガス化ガス からの入熱量の割合) を $60 \%$ と $70 \%$ で固定して発電運 転を行った時のデータを示す.いずれの場合も, 燃料ガ スの発熱量が変動しても, 燃料ガス投入流量の調整で 混焼率を一定に保つ運転が可能であることがこの運転 で確認できた. スモーク濃度は混焼率が 60\%と 70\%両 方ともボッシュユニットで 1 以下を示しており,NOx 濃度は約 $200 \mathrm{ppm}$ 以下の数值を示している事が分かっ た.この低 NOx 排出は, 文献 $(4,8)$ に記されているよう に, 混焼ディーゼルエンジンが持つ大きな特性の一つ である。

Table 5 Specification of the dual-fueled diesel engine

\begin{tabular}{c|c|c|c}
\hline \multirow{4}{*}{ Generator } & Output & $\mathrm{kWe}$ & 150 \\
\cline { 2 - 4 } & Type & - & Brushless three-phase AC \\
\cline { 2 - 4 } & & & Synchronous Generator \\
\cline { 2 - 4 } & Cycle & - & 60 \\
\cline { 2 - 4 } & Voltage & $\mathrm{V}$ & 6600 \\
\cline { 2 - 4 } & Power Factor & $\%$ & 80 \\
\hline \hline \multirow{5}{*}{ Engine } & Output & PS & 220 \\
\cline { 2 - 4 } & Type & - & $\begin{array}{c}\text { Water cooled T/C 4 stroke } \\
\text { engine }\end{array}$ \\
\cline { 2 - 4 } & $\begin{array}{c}\text { Combustion } \\
\text { system }\end{array}$ & & Gas co-firing diesel engine \\
\cline { 2 - 4 } & Cyl. No., B $\times$ S & & $6, \phi 130 \times 150$ (11.95L) \\
\cline { 2 - 4 } & Engine speed & $\mathrm{rpm}$ & 1800 \\
\cline { 2 - 4 } & Fuel & & Liquid:JS 1-2,Gas:Syngas \\
\cline { 2 - 4 } & $\begin{array}{c}\text { Fuel } \\
\text { consumption }\end{array}$ & $\mathrm{L} \mathrm{h}$ & 45.9 (at 100\% diesel) \\
\cline { 2 - 4 } & Engine oil & & JIS API-CD \\
\hline \hline
\end{tabular}

Table 6 Average gas composition and low heating value of the reformed gas during RUN3

\begin{tabular}{c|c|c|c|c|c|c|c}
\hline Item & $\mathrm{H}_{2}$ & $\mathrm{CO}$ & $\mathrm{CH}_{4}$ & $\mathrm{C}_{2} \mathrm{H}_{4}$ & $\mathrm{C}_{2} \mathrm{H}_{6}$ & $\mathrm{C}_{3} \mathrm{H}_{8}$ & $L \mathrm{LHV}\left[\mathrm{MJ} / \mathrm{m}_{\mathrm{N}}^{3}\right.$ \\
\hline \hline Gas composition(dry vol\%) & 6.44 & 14.14 & 2.18 & 0.92 & 0.01 & 0.15 & 3.95 \\
\hline
\end{tabular}

Table 7 Power generation tests during RUN3

\begin{tabular}{c|c|c}
\hline $\begin{array}{c}\text { Low Heating Value of the } \\
\text { Fuel gas (LHV) }\end{array}$ & Smoke & $\begin{array}{c}\text { Mixture rate of the Fuel gas } \\
\text { (LHV) and Light oil }\end{array}$ \\
\hline \hline$\left[\mathrm{MJ} / \mathrm{Nm}^{3}\right]$ & {$[\mathrm{BSU}]$} & {$[\%]$} \\
\hline 3.76 & 0.66 & 57 \\
3.78 & 0.6 & 57 \\
3.80 & 0.66 & 60 \\
4.17 & 0.44 & 57 \\
4.20 & 0.44 & 59 \\
\hline \hline 4.49 & $<1$ & 72 \\
4.60 & $<1$ & 70 \\
4.66 & $<1$ & 70 \\
4.95 & $<1$ & 72 \\
\hline \hline
\end{tabular}

\section{4. エネルギー 収支}

図 10 にRUN3 で実証されたシステム全体のエネル ギー収支を示す. 図中の（\%) で示した值は, システム に供給した燃料（廃衰物, 軽油, LPG）の総エネルギー 量を $100 \%$ とした時の相対的なエネルギー量である. 計算の結果, 炭素転換率は $93.3 \%$, 冷ガス効率は $53.9 \%$, 発電端効率は $10.8 \%$ となった. また図 11 には, RUN3 と 同じ組成の廃棄物を定格量である 1 トン/時供給した 時に予想されるエネルギー収支を示す. 計算の結果, 高温空気発生装置の熱効率が向上し，燃料ガスの所要 量が削減されたことなどによって，発電用燃料として 利用される燃料ガスの割合が増加し, システムの冷ガ ス効率が 59.1\%に, 発電端効率が 17.1\%にそれぞれ向上 することが期待されることがわかった。

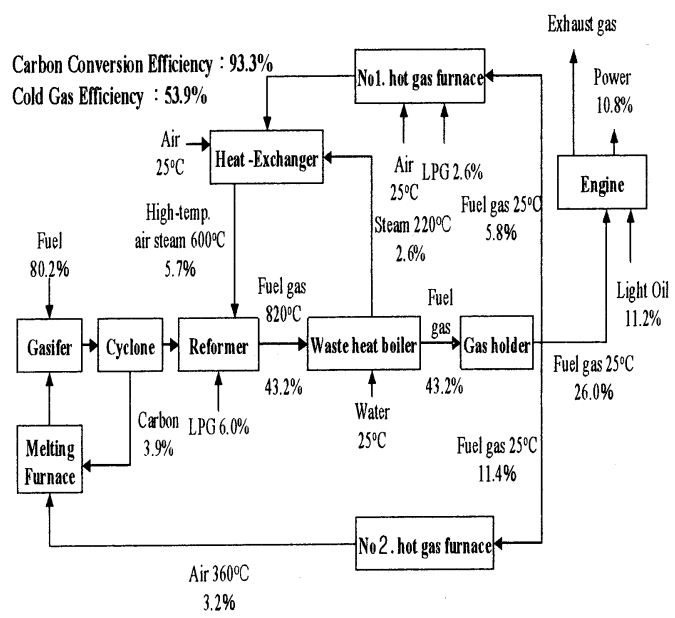

Fig.10 Demonstrated energy balance in the present operation

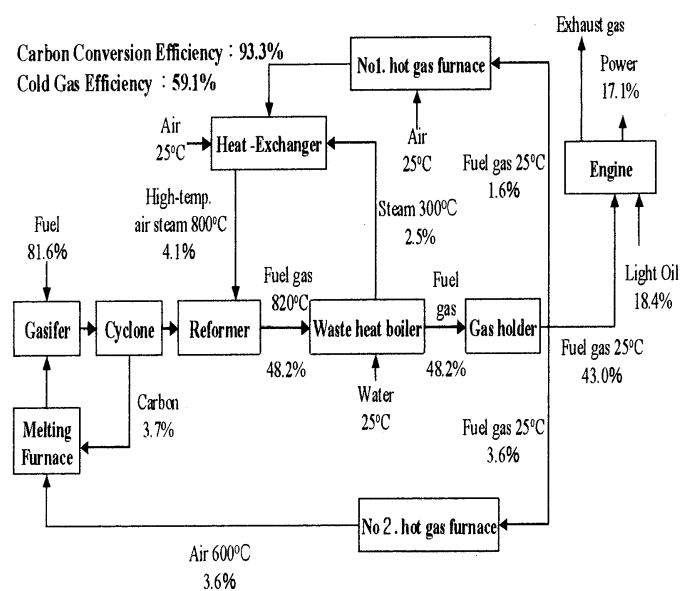

Fig.11 Estimated energy balance in the rated operation 


\section{5. 結 語}

一般廃棄物と肉骨粉を処理対象とする商用ガス化発 電システムの運転結果を解析することにより, 以下の 結論を得た。

1. 一般廃棄物と肉骨粉のみを燃料とする場合には, ガス化炉内で吹き抜け現象が発生し, 安定したガ ス化が行えないが, 木屑を混合させることでガス 化を安定化させることが可能であり,一般廃棄物 (30\%)肉骨粉(30\%)木屑(40\%)を混合させた運転の 場合, 定常的に低位発熱量 $3.8 \mathrm{MJ} / \mathrm{m}^{3} \mathrm{~N}$ 前後の安定 したガスが生成された.

2. 熱分解ガスに相当な変動があっても, 改質炉に供 給する高温空気量を調整することによって, 改質 炉温度をほぼ一定に維持でき, エンジン手前で計 測した改質ガス中のタール濃度は検出限界以下で あった.ただし, 改質炉に供給する高温空気量を増 やすと, 改質ガスの低位発熱量は低下する.

3. 低位発熱量 $3.8 \mathrm{MJ} / \mathrm{m}^{3} \mathrm{~N}$ 前後のガスで混焼ディー ゼルエンジンを運転した結果から, 発熱量の変動に 対しても混焼率 60 70\%で安定した発電が可能で あり,排気ガス中のスモークは1BSU 以下, NOx は 200ppm 以下である事が分かった.

4. 定格の約半分の廃棄物供給量での運転で実証され たシステム全体のエネルギー収支に基づいて, 定格 量の廃棄物を供給する場合のエネルギー収支を予 測した結果, 冷ガス効率 $59.1 \%$, 発電端効率 $17.1 \%$ が 得られることが期待される.

\section{文献}

(1) Sumio, Y.et al., Thermoselect Waste Gasification and Reforming Process, JFE Engineering Report, No.3 (2004.3), pp.20-24

(2) Kidoguchi, A., Development of a Gasifer for Biomass and Waste Materials, Mitsui Shipbuiding \& Engineering Repont, No.185(2005. 6), pp.9-14

(3) Hashimoto, Y.et al., R\&D on Micro-gasifer for Power Generation from Biomass Fuels, The $9^{\text {th }}$ National Sympoxim on Power and Energy Systems,No.04-2(2004.6),pp. 193-194

(4) T.J, Min. et al., A study on Duel-fueled Diesel Engine for waste Gasification and Power Generation, Transactions of the Japan Society of Mechanical Engineers,SeriesB,Vol.70,No.697(2004),pp.2468-2473

(5) Abe, T. et al., Performance of Waste Gasification and Power Generation of a Small Scale Plant, Proceedings of the 13th Annual Meeting of the Japan Institute of Energy, (2004), pp.288-289

(6) Sato, K. et al., Studies on pyrolysis/reforming gasification and power generation system for cow dung, Proceedings of the 13th Annual Meeting of the Japan Institute of Energy, (2004), pp.198-199

(7) Hara, T. et al., Performance Demonstration of Gasification and Power Generation from Woody Biomass, Journal of the Japan Institute of Energy, Vol.83,No.10(2004),pp. 815-820

(8) T. J, Min. et al., Distributed gasification and power generation from solid wastes, Journal of the Energy, Vol. $30,(2005)$, pp.2219-2228

(9) Hara, T., Yoshikawa, K., Gasifiction Performance of Various Solid Wastes Using a Pyrolysis/Reforming Gasification Process, 6th International Symposium on High Temperature Air Combustion and Gasification, (2005) 